\title{
Perancangan Sistem Informasi Pendataan Anggota Poliklinik UPN "Veteran" Jawa Timur
}

\author{
Retno Mumpuni ${ }^{1}$, Fetty Tri Anggraeny ${ }^{2}$, Mochamad Nor Fadillah ${ }^{3}$ \\ 1,L,3 Jurusan Teknik Informatika, UPN “Veteran” Jawa Timur, Surabaya, Indonesia \\ Email: retnomumpuni.peni@gmail.com
}

\begin{abstract}
PT)
Polyclinic as one of the community service institutions requires management improvement, especially regarding patient data collection. The UPN "Veteran" Polyclinic in East Java is still using manual paper based data collection. Paper based systems require storage space to store documents and difficult to extract information based on paper-based data stored. Therefore in this study we will design a Polyclinic Data Collection Information System to improve service quality and improve the polyclinic evaluation process using the waterfall method and web-based applications. The system design includes process design, database and interface. The design has been validated by the user and declared to have answered the problem.
\end{abstract}

Keyword : information system, polyclinic, patient data collection

\begin{tabular}{l}
\hline ABSTRAK (10 PT) \\
\hline Poliklinik sebagai salah satu lembaga layanan masyarakat membutuhkan perbaikan manajemen \\
terutama mengenai pendataan pasien. Poliklinik UPN "Veteran" Jawa Timur saat ini masih \\
menggunakan pendataan secara manual paper based. Sistem paper based membutuhkan ruang \\
penyimpanan untuk menyimpan dokumen dan sulit dilakukan penggalian informasi berdasarkan data \\
paper based yang tersimpan. Oleh karena itu dalam penelitian ini akan membuat rancangan Sistem \\
Informasi Pendataan Anggota Poliklinik untuk meningkatkan kualitas layanan dan meningkatkan \\
proses evaluasi poliklinik menggunakan metode waterfall dan aplikasi berbasis web. Rancangan \\
sistem antara lain rancangan proses, basis data dan antarmuka. Rancangan tersebut sudah di validasi \\
oleh pengguna dan dinyatakan sudah menjawab permasalahan. \\
Kata kunci : sistem informasi, poliklinik, pendataan pasien
\end{tabular}

\section{PENDAHULUAN}

Kesehatan merupakan hal yang penting dalam menunjang kegiatan civitas akademik di suatu Perguruan Tinggi. UPN "Veteran" Jawa Timur sebagai salah satu Perguruan Tinggi Negeri di Indonesia memiliki layanan kesehatan Poliklinik yang dikelola secara internal. Menurut Peraturan Menteri Kesehatan Republik Indonesia Nomor 9 Tahun 2014, klinik adalah fasilitas pelayanan kesehatan yang menyelenggarakan pelayanan kesehatan perorangan yang menyediakan pelayanan medis dasar dan/atau spesialistik [1]. Poliklik UPN memberikan layanan kesehatan tidak hanya untuk civitas akademik tetapi juga masyarakat umum. Seiring dengan perkembangan kampus UPN 'Veteran' Jawa Timur yang telah menjadi BLU (Badan Layanan Umum), maka peningkatan kualitas pelayanan kesehatan menjadi hal yang mutlak harus dipenuhi di lingkungan kampus. Saat ini pelayanan kesehatan di poliklinik UPN belum optimal, hal ini dikarenakan belum ada data anggota yang lengkap dan rapi tertata. Selain itu pendataan anggota saat ini masih paper based sehingga sulit bagi pengurus menggali informasi dari data pasien maupun data layanan. Kemampuan suatu lembaga untuk menggali informasi dari kegiatan bisnis sangat penting untuk mengetahui tolok ukur kinerja.

Untuk membantu peningkatan pelayanan kesehatan Poliklinik UPN "Veteran" Jawa Timur, maka penelitian ini mengusulkan membuat rancangan sistem informasi pendataan untuk memfasilitasi pendaftaran anggota. Khusus civitas akademik UPN "Veteran" Jatim baik dosen, tenaga kependidikan maupun mahasiswa akan secara otomatis terdaftar sebagai anggota poliklinik. Sedangkan masyarakat umum dapat melakukan pendaftaran dengan datang langsung ke poliklinik dan menemui petugas pendaftaran. Sistem informasi pendataan anggota dibangun berbasis web dengan harapan ke depan tidak hanya diakses dari lingkungan poliklinik tetapi juga dari luar poliklinik oleh konsumen secara langsung. Penelitian di bidang 


\section{ELKOM “Jurnal Teknik Elektro Dan Komputasi”}

Vol. 1, No. 1, Agustus 2019, Hal: 46-54

ISSN: , DOI: , Terakreditasi Dikti dengan SK:

pencatatan data pasien sudah sangat banyak dilakukan dengan studi kasus poliklinik atau instansi layanan kesehatan lain antara lain mengklasifikasikan teknik terapis, prosedur klinis dan keperawatan serta merumuskan diagnosis berdasarkan data aplikasi rumah sakit SNOMED [2], pengembangan rekam medis elektronik menggunakan metode Agile [3], perbandingan pembuatan aplikasi layanan kesehatan menggunakan metode pengembangan perangkat lunak waterfall, incremental, agile, dan SEMHTA [4].

Dalam membangun suatu sistem informasi diperlukan metode pengembangan perangkat lunak atau System Development Life Cycle (SDLC), salah satunya adalah waterfall. Metode pengembangan perangkat lunak waterfall merupakan metode pengembangan sistem pertama yang diusulkan oleh Winston W. Royce pada tahun 1970 [5]. Waterfall original tidak memungkinkan terjadinya proses berulang di setiap tahapnya ataupun kembali ke tahap sebelumnya karena sesuai namanya "air terjun", air yang jatuh tidak mungkin kembali ke atas. Bassil (2012) melakukan simulasi waterfall yang memungkinkan adanya perulangan proses di tahap yang sama atau kembali ke tahapan-tahapan sebelumnya [6]. Penelitian sebelumnya yang menggunakan waterfall sebagai metode pengembangan perangkat lunaknya antara lain pembuatan sisten informasi geografis [7], system informasi SDM berprestasi [8], system informasi praktek kerja lapangan [9], system informasi alumi [10], system informasi manajemen arsip [11]. Sedangkan penelitian sebelumnya yang terkait dengan system informasi yang menggunakan institusi kesehatan (poliklinik, puskesmas, rumah sakit) antara lain system manajemen arsip rumah sakit [11], aplikasi rekam medis [12], system informasi klinik [13], system pengarsipan data pasien [14], system informasi administrasi pasien [15], system rekam medis [16], system manajemen klinik dan rekam media [17].

Dalam penelitian ini akan dibangun Sistem Informasi Pendataan Anggota Poliklinik UPN "Veteran" Jawa Timur menggunakan metode pengembangan perangkat lunak waterfall. Sehingga mampu menjawab permasalahan pencatatan pasien, kegiatan layanan dan pelaporan kinerja poliklinik.

\section{METODOLOGI}

Metodologi penelitian menggunakan metode pengembangan software waterfall, yang meliputi tahapan analisa kebutuhan, perancangan, pengkodean, pengujian, dan pemeliharaan, seperti yang tampak pada Gambar 1 [18].

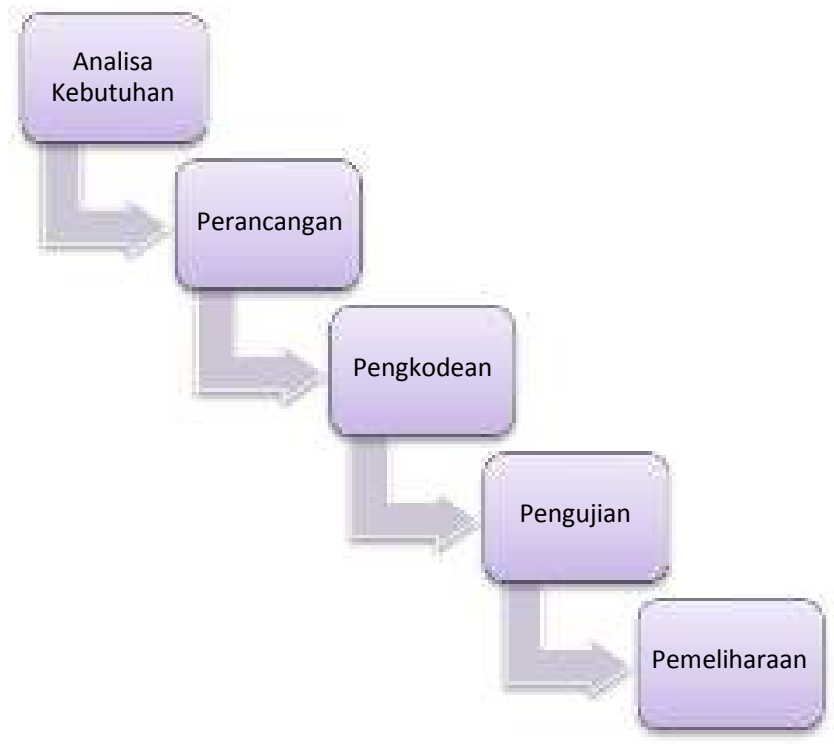

Gambar 1. Metodologi penelitian

Analisa Kebutuhan

Tahapan ini dapat dilakukan dengan 3 metode, yaitu observasi, wawancara, dan studi pustaka. Observasi melakukan pengamatan secara langsung di Poliklinik untuk mengetahui proses layanan kesehatan dilakukan oleh komponen pengurus Polilkinik. Wawancara dilakukan kepada komponen pengurus poliklinik, meliputi dokter dan perawat, untuk mengetahui standar operasional prosedur layanan kesehatan, siapa saja pasien yang datang, jenis layanan yang diberikan, dan pencatatan dokumen yang dilakukan.

Perancangan

Dalam tahapan ini hasil analisa kebutuhan diubah kedalam bentuk dokumen rancangan sistem. Dokumen rancangan yang disusun terdiri dari UML, struktur penyimpanan data (basis data), dan antarmuka. Diagram 


\section{ELKOM “Jurnal Teknik Elektro Dan Komputasi”"}

Vol. 1, No. 1, Agustus 2019, Hal: 46-54

ISSN: , DOI: , Terakreditasi Dikti dengan SK:

alir digunakan untuk menjelaskan proses yang terjadi dalam system. Struktur basis data sebagai media penyimpanan data yang dibutuhkan dalam penerapan SIPONIK. Dan desain antarmuka untuk mengetahui gambaran antarmuka yang diterapkan di SIPONIK. Penelitian ini akan fokus pada pembahasan perancangan dari SIPONIK, khusus UML dan basis data.

\section{Pengkodean}

Sistem akan dibuat berbasis web dengan operator internal Poliklinik menggunakan framework Code Page 48 Ignitier (CI). Program dibuat berdasarkan hasil requirement dan perancangan yang telah dilakukan.

Pengujian

Dilakukan untuk mengetahui apakah system sudah berjalan sesuai dengan analisa kebutuhan dan perancangan.

\section{HASIL DAN PEMBAHASAN}

\subsection{Analisa Kebutuhan}

Poliklinik saat ini masih menggunakan system manual, dimana data setiap anggota poliklinik disimpan dalam bentuk kertas yaitu kartu anggota yang dibawa oleh si anggota dan kartu rekamedis yang disimpan di poliklinik. Beberapa periode terakhir terjadi ketidaktertiban pencatataan anggota maupun layanan kesehatan, dikarenakan sulitnya mengetahui apakah pasien sudah terdaftar sebagai anggota sehingga terjadi masalah dalam pencarian dan pencatatan data rekamedis. Mengingat UPNVJATIM yang saat ini adalah Perguruan Tinggi BLU, maka perlu dilakukan peningkatan kualitas pelayanan kesehatan sehingga akan meningkatkan kuantitas layanan. Karena masih menggunakan pencatatan manual dan ketidaktertiban pencatatan maka muncul kesulitan ketika diperlukan data terkait kinerja Poliklinik dalam tugasnya memberikan layanan kesehatan. Maka sebagai tahap awal adalah dibuatnya sistem pendataan anggota poliklinik yang digunakan secara internal poliklinik yang dioperasikan oleh salah satu perawat. Seluruh data pribadi awal civitas akademis, baik dari sisi dosen, tenaga kependidikan, maupun mahasiswa akan disimpan dalam basis data Sistem Pendaftaran Poliklinik. Sedangkan data dari masyarakat umum akan dilakukan pendaftaran ulang ketika masyarakat berkunjung ke Poliklinik untuk berobat. Sistem yang dibuat mampu mencetak kartu anggota dan kartu rekam medis.

\subsection{Perancangan}

Berdasarkan analisis yang telah dilakukan maka dilakukan perancangan Sistem Informasi Pendataan Anggota Poliklinik dengan diagram arsitektur seperti pada Gambar 2.

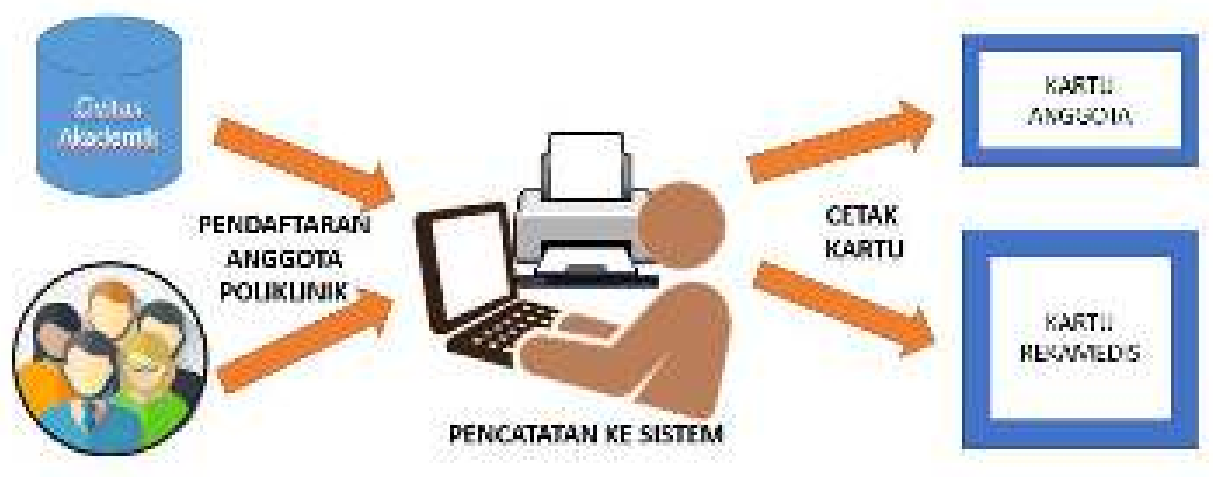

Gambar 2 Diagram Sistem SIPONIK.

Perancangan Sistem Informasi Pendataan Anggota Poliklinik meliputi perancangan system dan basisdata. Karena aplikasi terbatas pada internal poliklinik dan dioperasikan oleh garda depan poliklinik, maka hanya disediakan 1 jenis user, yaitu admin. Beberapa proses bisnis yang dibutuhkan antara lain:

Tabel 1. Proses Bisnis SIPONIK

\begin{tabular}{|l|l|}
\hline \multicolumn{1}{|c|}{ Proses Bisnis } & \multicolumn{1}{c|}{ Keterangan } \\
\hline Master dokter & $\begin{array}{l}\text { Digunakan untuk melakukan penambahan, penghapusan dan } \\
\text { pengubahan data dokter }\end{array}$ \\
\hline Master perawat & Digunakan untuk melakukan penambahan, penghapusan dan \\
\hline
\end{tabular}


ELKOM “Jurnal Teknik Elektro Dan Komputasi”"

Vol. 1, No. 1, Agustus 2019, Hal: 46-54

ISSN: , DOI: , Terakreditasi Dikti dengan SK:

\begin{tabular}{|l|l|}
\hline & pengubahan data perawat \\
\hline Master fakultas & $\begin{array}{l}\text { Digunakan untuk melakukan penambahan, penghapusan dan } \\
\text { pengubahan data fakultas }\end{array}$ \\
\hline Master jurusan atau program studi & $\begin{array}{l}\text { Digunakan untuk melakukan penambahan, penghapusan dan } \\
\text { pengubahan data jurusan atau program studi }\end{array}$ \\
\hline $\begin{array}{l}\text { Manajemen data anggota (dosen, staf, } \\
\text { mahasiswa, umum) }\end{array}$ & $\begin{array}{l}\text { Menampilkan seluruh data anggota, dan disertai fitur } \\
\text { menghapus dan mengubah data anggota tertentu }\end{array}$ \\
\hline Pendaftaran anggota & $\begin{array}{l}\text { Halaman untuk proses pendaftaran anggota poliklinik secara } \\
\text { individu }\end{array}$ \\
\hline Impor data anggota & $\begin{array}{l}\text { Digunakan untuk mengimpor data calon anggota dari civitas } \\
\text { akademik UPNVJATIM dalam bentuk file excel }\end{array}$ \\
\hline Cetak kartu anggota & Mencetak kartu anggota yang nantinya dibawa oleh anggota \\
\hline Cetak kartu rekamedis & $\begin{array}{l}\text { Mencetak kartu rekamedis yang nantinya disimpan di } \\
\text { poliklinik }\end{array}$ \\
\hline
\end{tabular}

Rancangan menu

Proses bisnis pada Tabel 1 dipetakan ke dalam menu-menu seperti pada Gambar 3. Menu pertama adalah Dashboard yang akan menampilkan laporan-laporan visual terkait pendataan anggota poliklinik, meliputi laporan jumlah akumulasi tiap kelompok anggota, laporan pendaftaran kunjungan pasien dalam 1 tahun terakhir yang dibedakan berdasarkan jenis anggota baik berbentuk grafik maupun teks, serta list data pendaftaran kunjungan pasien pada hari ini. Menu kedua adalah adalah Pendaftaran, menu ini untuk mendata kunjungan anggota untuk berobat ke poliklinik. Menu ini dilengkapi submenu pendaftaran baru dan riwayat pendaftaran. Menu ketiga adalah Anggota, berfungsi menampilkan data anggota poliklinik pada setiap nis anggota mahasiswa, dosen, staff, dan masyarakat umum. Menu keempat adalah Pegawai, sebagai master data dari dokter dan perawat. Menu kelima adalah Setting untuk melakukan manajemen master fakultas dan jurusan.

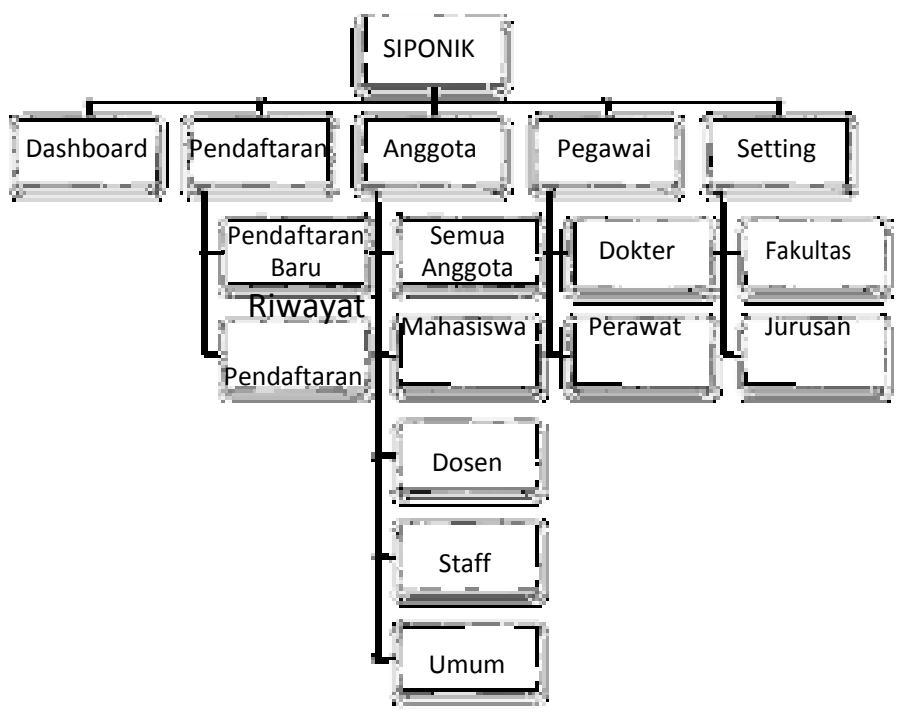

Gambar 3. Rancangan menu.

Rancangan Proses

Use case terdiri master (dokter, perawat, fakultas dan jurusan), manajemen data anggota (dosen, staf, mahasiswa, dan umum), pendaftaran anggota, impor data anggota, cetak kartu anggota dan cetak kartu rekam medis. Use case cetak kartu anggota dan cetak kartu rekam medis dilakukan di area manajemen data anggota, begitu pula use case impor data anggota. 
ELKOM “Jurnal Teknik Elektro Dan Komputasi”

Vol. 1, No. 1, Agustus 2019, Hal: 46-54

ISSN: , DOI: , Terakreditasi Dikti dengan SK:

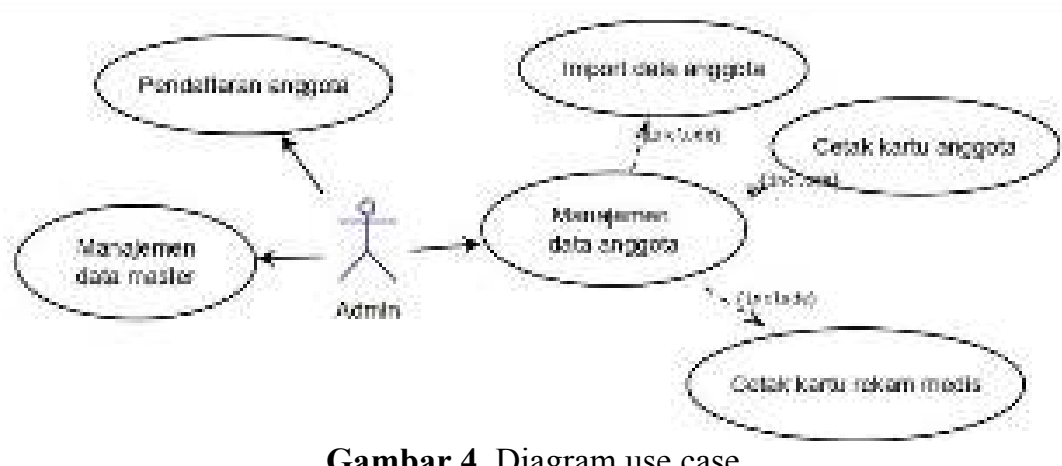

Page $\mid 50$

Gambar 4. Diagram use case.

Activity diagram proses pendaftaran anggota terdiri dari memasukkan data pribadi anggota dan data medis meliputi gejala dan riwayat obat serta dokter. Hal ini digunakan untuk menggali informasi awal dari anggota ketika pasien melakukan kunjungan berobat.

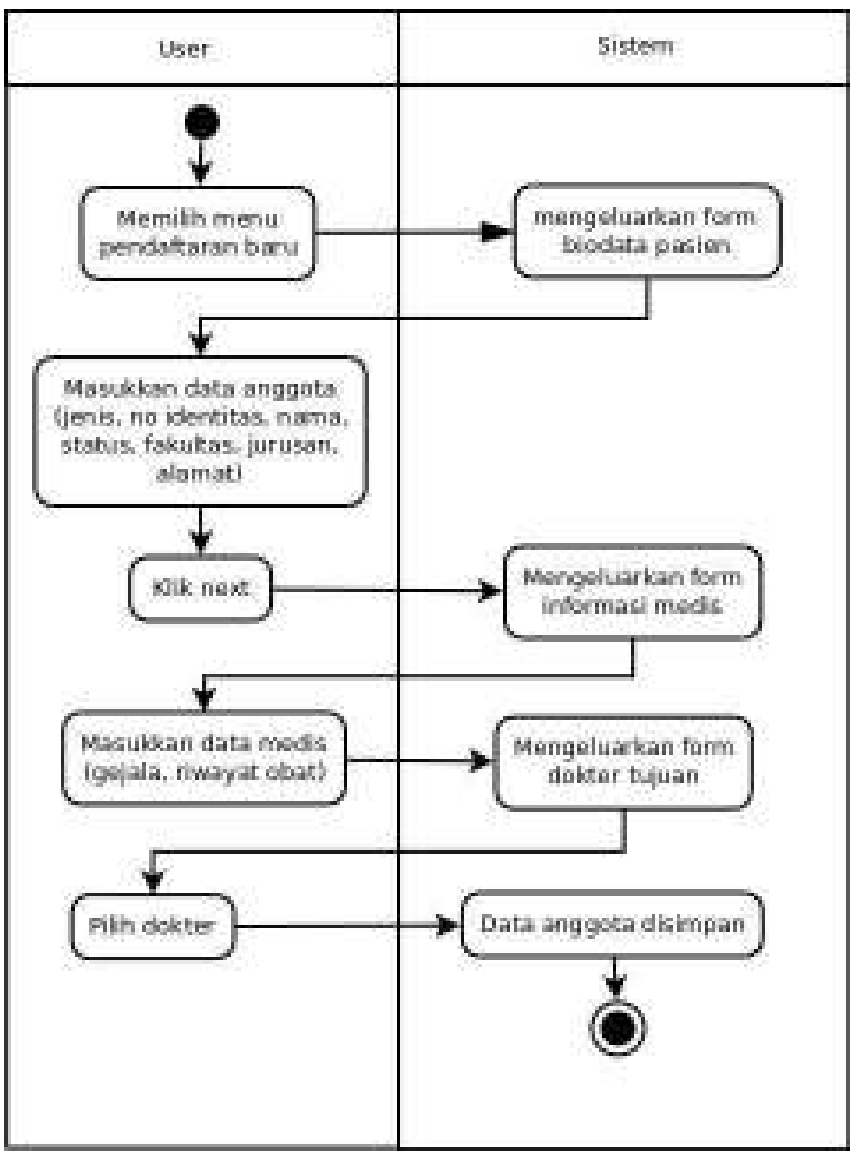

Gambar 5. Activity diagram pendaftaran anggota.

Rancangan Basis Data

Penyimpanan data yang dibutuhkan menggunakan rancangan basis data pada Gambar 10. Tabel master terdiri dari tabel perawat, dokter, jurusan, dan fakultas. Untuk pencatatan pendataan anggota disimpan pada tabel anggota. Sedangkan pencatatan kunjungan anggota untuk berobat disimpan dalam tabel antrian dan rekam medis. 
ELKOM “Jurnal Teknik Elektro Dan Komputasi”

Vol. 1, No. 1, Agustus 2019, Hal: 46-54

ISSN: , DOI: , Terakreditasi Dikti dengan SK:

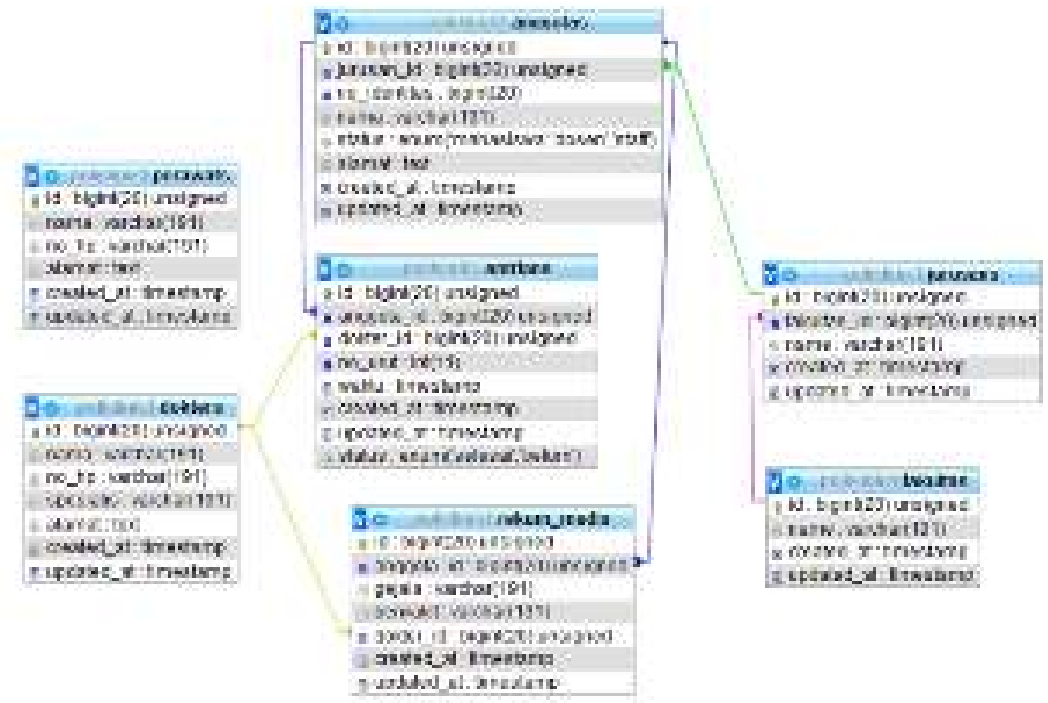

Page $\mid 51$

Gambar 10. Rancangan basis data.

Rancangan Antarmuka

Berdasarkan proses bisnis table 1, Gambar 3 dan rancangan proses, maka dibuat rancangan antarmuka yang mendukung sebagai sarana interaksi dengan pengguna. Gambar 11 adalah tampilan awal dashboard. Pada bagian dashboard menampilkan data-data yang bersifat laporan aktivitas terhadap system.

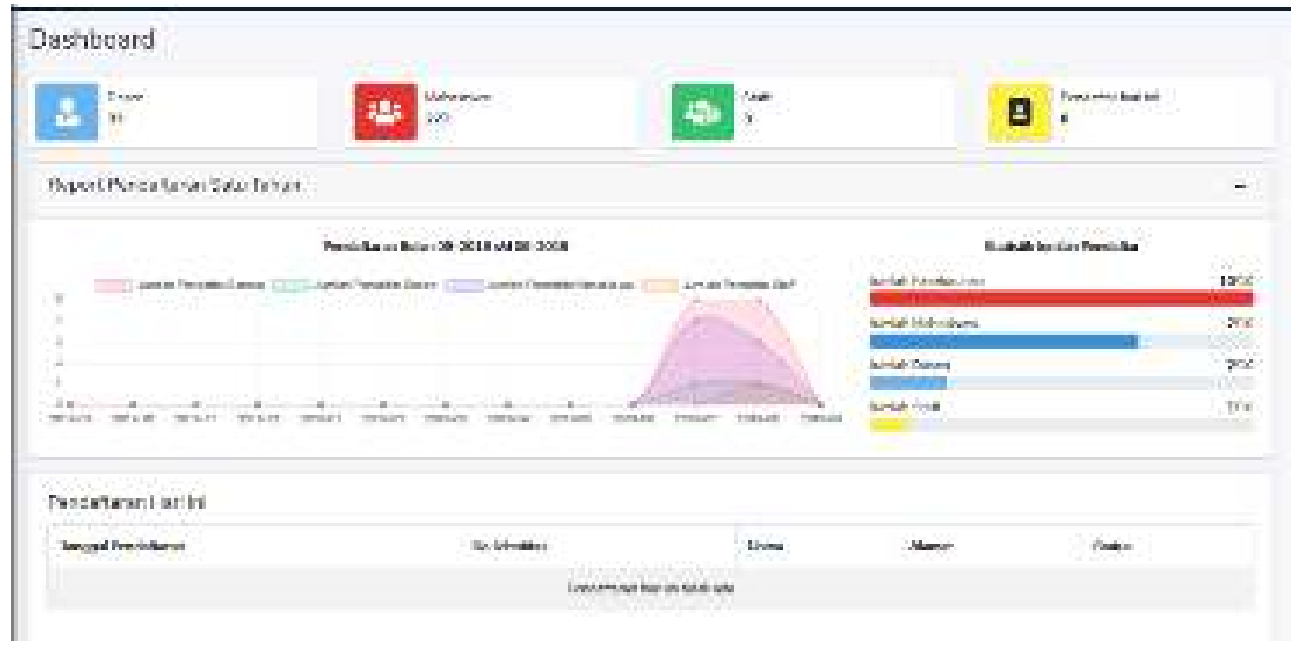

Gambar 11. Rancangan antarmuka dashboard.

Menu kedua adalah pendaftaran, menu ini terbagi menjadi 2 fungsi yaitu pendataan anggota baru dan pendaftaran pasien berobat dan terbagi menjadi 3 tab tahap pengisian yaitu biodata pasien (Gambar 12), informasi medis (Gambar 13), dan pilih layanan (Gambar 14). Pendataan anggota baru dapat dilakukan dengan memilih pilihan radio button jenis pasien "Baru" kemudian mengisi data pribadi anggota di sebelah kanan. Jika sudah terdaftar, maka pilih radio button jenis pasien "Lama" dan memasukkan nama pasien di isian "Cari Pasien". Pada tab kedua, informasi medis, berisi keluhan/gejala dan riwayat obat yang dikonsumsi. Dan pada tab ketiga, pilih layanan untuk memilih dokter yang dituju. 


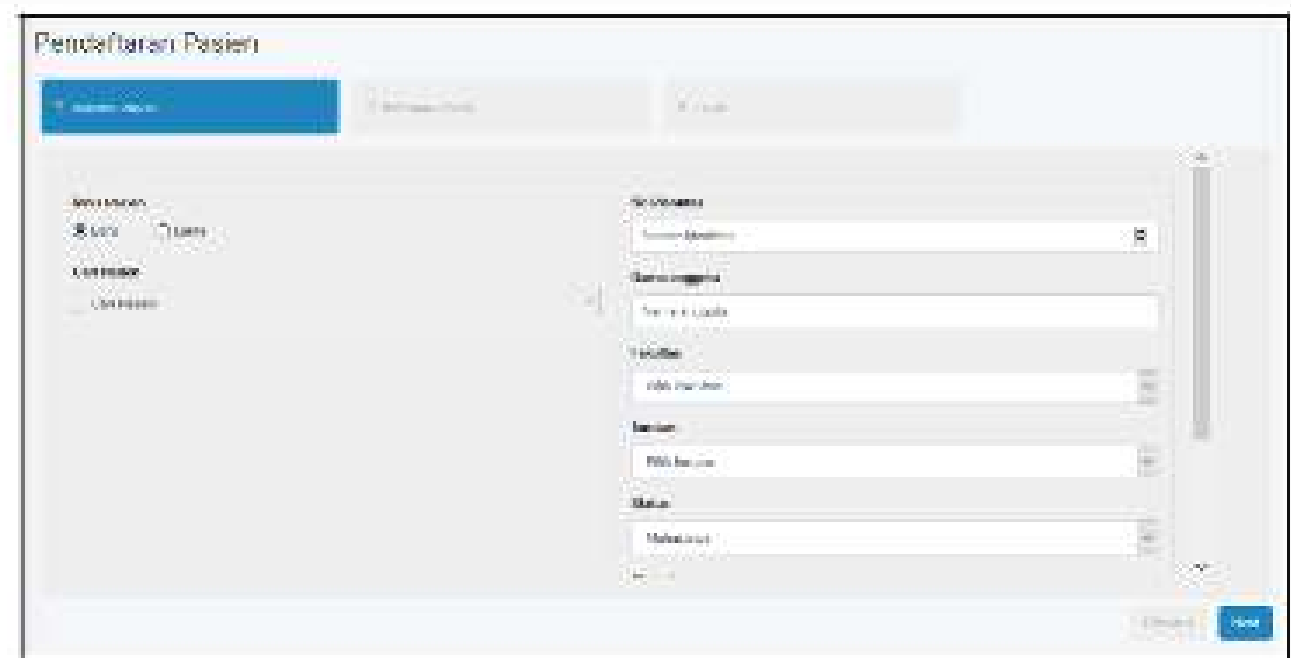

Gambar 12. Form pendaftaran pasien tab biodata pasien.

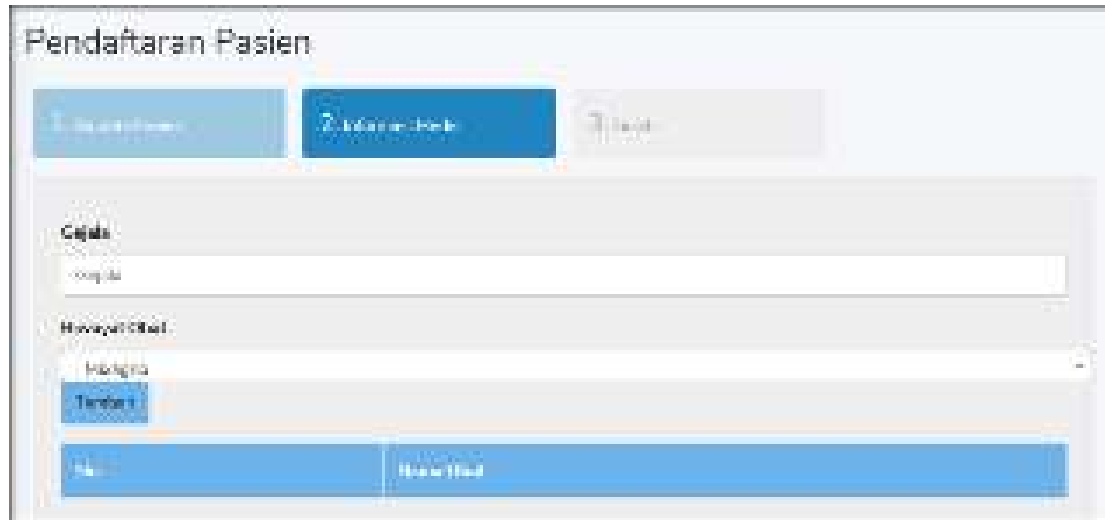

Gambar 13. Form pendaftaran pasien tab informasi medis.

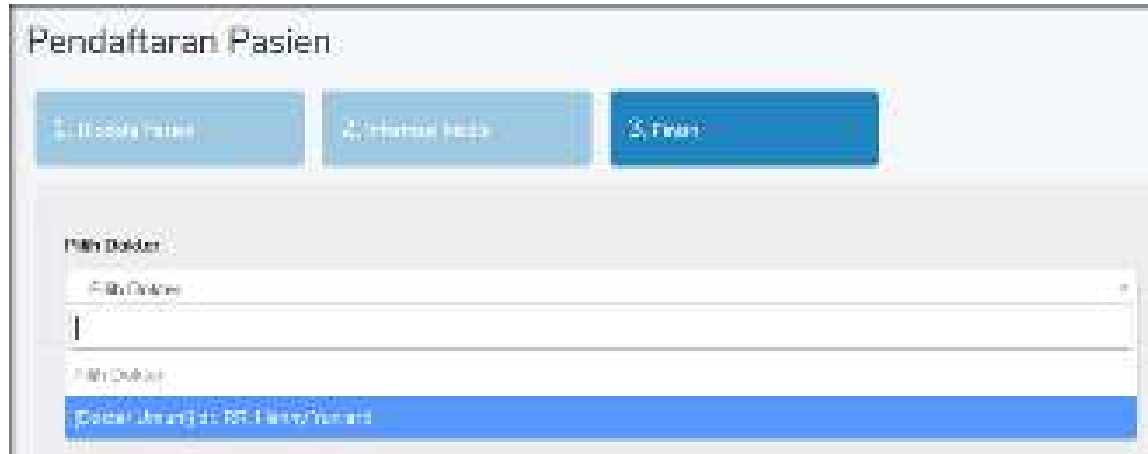

Gambar 14. Form pendaftaran pasien tab pilih dokter.

\section{KESIMPULAN}

Rancangan aplikasi pendataan pasien poliklinik sudah dibuat berdasarkan permintaan dari pihak poliklinik dan telah mampu memberikan gambaran yang lengkap mengenai ruang lingkup aplikasi yang akan dibuat. Rancangan terdiri dari rancangan proses bisnis, antarmuka dan basisdata. Dan rancangan yang dibuat sudah memenuhi kebutuhan dan menjawab permasalahan utam yang muncul di Poliklin UPN "Veteran" Jawa Timur.

\section{REFERENSI}

[1] Indonesia, K.K.R., 2014. Peraturan Menteri Kesehatan Republik Indonesia Nomor 9 Tahun 2014 Tentang Klinik.

[2] Duarte, J., Castro, S., Santos, M., Abelha, A. and Machado, J., 2014. Improving quality of electronic health records with SNOMED. Procedia Technology, 16, pp.1342-1350. 
[3] Schutzbank, A. and Fernandopulle, R., 2014, March. Doubling down: Lessons learned from building a new electronic health record as part of primary care practice redesign. In Healthcare (Vol. 2, No. 1, pp. 14-18). Elsevier.

[4] Al-Dahmash, A. and El-Masri, S., 2013. A New Proposed Software Engineering Methodologyfor Healthcare Applications Development. Int. J. Mod. Eng. Res, 3(3), pp.1566-1570

[5] Royce, W., "Managing the Development of Large Software Systems", Proceedings of IEEE WESCON 26, pp.1-9,1970.

[6] Bassil, Y., 2012. A Simulation Model for the Waterfall Software Development Life Cycle. International Journal of Engineering and Technology, 2(5).

[7] Sasmito, G.W., 2017. Penerapan Metode Waterfall Pada Desain Sistem Informasi Geografis Industri Kabupaten Tegal. Jurnal Informatika: Jurnal Pengembangan IT, 2(1), pp.6-12.

[8] Sari, D.P., Febriani, O.M. and Putra, A.S., 2018, November. Perancangan Sistem Informasi SDM Berprestasi pada SD Global Surya. In Prosiding Seminar Nasional Darmajaya (Vol. 1, No. 1, pp. 289294).

[9] Safitri, S.T. and Supriyadi, D., 2015. Rancang Bangun Sistem Informasi Praktek Kerja Lapangan Berbasis Web dengan Metode Waterfall. Jurnal Infotel, 7(1), pp.69-74.

[10] Romadhoni, E.N.A., Widiyaningtyas, T. and Pujianto, U., 2015. Implementasi Model Waterfall Pada Pengembangan Sistem Informasi Alumni SMKN 1 Jenangan Ponorogo. SESINDO 2015, 2015.

[11] Pascapraharastyan, R.A., Supriyanto, A. and Sudarmaningtyas, P., 2014. Rancang Bangun Sistem Informasi Manajemen Arsip Berbasis Web Pada Rumah Sakit Bedah Surabaya. Jurnal JSIKA, 3(1), pp.139-143.

[12] Al Faruq, U., 2015. Rancang bangun aplikasi rekam medis poliklinik universitas trilogi. Jurnal Informatika Ahmad Dahlan, 9(1).

[13] Salim, R.R.M., 2013. Pengembangan Sistem Informasi Klinik Berbasis Web. SESINDO 2013, 2013.

[14] Subhiyakto, E.R., Astuti, Y.P., Umaroh, L., Utomo, D.W., Rachmawanto, E.H. and Sari, C.A., 2017. Rancang bangun sistem informasi pengarsipan data pasien klinik cemara. Techno. com, 16(1), pp.25-34.

[15] Utami, L.A., 2014. Sistem Informasi Administrasi Pasien pada Klinik Keluarga Depok. Konferensi Nasional Ilmu Pengetahuan dan Teknologi, 1(1), pp.33-38.

[16] Sinaga, R. and Nurhadi, N., 2016. ANALISIS DAN PERANCANGAN SISTEM INFORMASI REKAM MEDIS PADA KLINIK AKPER KESDAM II/SRIWIJAYA GARUDA PUTIH. Jurnal Manajemen Sistem Informasi, 1(1), pp.67-79.

[17] Triaji, Y.W., Kridalukmana, R. and Widianto, E.D., 2017. Pembuatan Sistem Informasi Manajemen Klinik dengan Rekam Medis: Studi Kasus di Klinik Kebon Arum Boyolali. Jurnal Teknologi dan Sistem Komputer, 5(1), pp.15-22.

[18] Jogiyanto, "Metodologi Penelitian Sistem Informasi”, CV Andi Offset. Yogyakarta, 2008.

\section{RIWAYAT HIDUP PENULIS (10 PT)}

\begin{tabular}{l|l} 
Retno Mumpuni, lahir di Ponorogo tahun Juli 1987. Meraih gelar Sarjana Komputer \\
(S.Kom) dari program studi Teknik Informatika Institut Teknologi Sepuluh Nopember (ITS) \\
Surabaya pada tahun 2011. Kemudian gelar Master Computer Science (M.Cs) dari \\
program studi Computer Science National Taiwan University of Science and \\
Technology pada tahun 2015. Bertugas sebagai Dosen di UPN "Veteran" Jawa Timur \\
Program Studi Teknik Informatika sejak tahun 2016 sampai sekarang. Penulis dapat \\
dihubungi pada alamat email: retnomumpuni.peni@gmail.com.
\end{tabular}




\section{ELKOM “Jurnal Teknik Elektro Dan Komputasi”"}

Vol. 1, No. 1, Agustus 2019, Hal: 46-54

ISSN: , DOI: , Terakreditasi Dikti dengan SK:

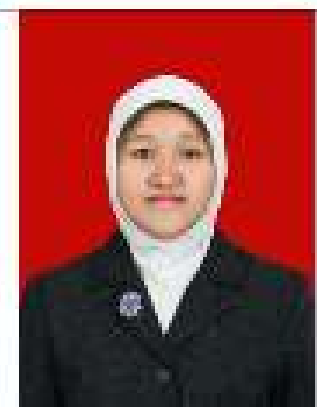

Fetty Tri Anggraeny, lahir di Surabaya tahun 1982. Meraih gelar Sarjana Komputer (S.Kom) dari program studi Teknik Informatika Institut Teknologi Sepuluh Nopember (ITS) Surabaya pada tahun 2005. Kemudian gelar Master Komputer (M.Kom) dari program studi Teknik Informatika Institut Teknologi Sepuluh Nopember (ITS) Surabaya pada tahun 2012. Bertugas sebagai Dosen di UPN "Veteran" Jawa Timur Program Studi Teknik Informatika sejak tahun 2006 sampai sekarang. Penulis dapat dihubungi pada alamat email:

fettyanggraeny.if@upnjatim.ac.id. 